\title{
Gas exchange, photosystem II photochemistry, and the antioxidant system of longan plant (Dimocarpus longan Lour.) leaves in response to lead (Pb) stress
}

\author{
Yanna Wang, Yongyu Li, Cuilan Ma, Dongliang Qiu* \\ College of Horticulture, Fujian Agriculture and Forestry University, Fuzhou, 350002, China
}

*Corresponding author: qiudl1970@fafu.edu.cn

\begin{abstract}
Longan is one of the most important subtropical fruit trees and a famous special product in south China. Increased fruit demand brings longan cultivation to Pb-affected regions. Seedlings of longan (cv. Wulongling) in pots with sands were irrigated daily for $30 \mathrm{~d}$ with a freshly prepared nutrient solution containing different concentrations of $\mathrm{Pb}\left(\mathrm{NO}_{3}\right)_{2}(0,100,200,400,600,800$ and 1000 $\mathrm{mg} \mathrm{L}^{-1}$ ) to determine physiological and biochemical responses of longan seedlings to various levels of lead (Pb). The results indicated that $\mathrm{Pb}$ stress substantially inhibited the growth of longan plants and markedly declined in their dry biomass. However, when the plants were grown at $100 \mathrm{mg} \mathrm{L}^{-1} \mathrm{~Pb}$, the growth and dry biomass of the plants showed no significant difference from control. In addition, the chlorophyll a fluorescence and gas exchange parameters were correlated with the growth and yield response. $\mathrm{Pb}$ treatments increased the minimum fluorescence $(\mathrm{Fo})$ and caused a decrease in maximum fluorescence $(\mathrm{Fm})$, variable fluorescence $(\mathrm{Fv})$, the maximum quantum efficiency of PSII photochemistry ( $\mathrm{Fv} / \mathrm{Fm})$, trapped energy flux per cross section (CS) at $\mathrm{t}=0$ (TRo/CSo), electron transport flux per $\mathrm{CS}$ at $\mathrm{t}=0$ (ETo/CSo), dissipated energy flux per CS at $\mathrm{t}=0(\mathrm{DIo} / \mathrm{CSo})$, and the amount of active PSII reaction centers (RCs) per $\mathrm{CS}$ at $\mathrm{t}=0(\mathrm{RC} / \mathrm{CS}$ ). Furthermore, $\mathrm{Pb}$ stress led to decreases in the protein contents, the activity of peroxidase (POD, EC 1.11.1.7) and the accumulation of proline and malondialdehyde (MDA), and enhanced superoxide dismutase activity (SOD, EC 1.15.1.1), whereas catalase (CAT, EC 1.11.1.6) and ascorbate peroxidase (APX,EC 1.11.1.11) were enhanced at low Pb levels and decreased under high $\mathrm{Pb}$ stress. Nonetheless, these changes were closely related to the severity of the $\mathrm{Pb}$ stress.
\end{abstract}

Keywords: Dimocarpus longan Lour.; Gas exchange; Chlorophyll a fluorescence; Chlorophyll content; Antioxidant enzymes; $\mathrm{Pb}$ stress.

Abbreviations: APX_ascorbate peroxidase; Car_carotenoid; CAT_catalase; Chl a_chlorophyll a; Chl b_chlorophyll b; Chl a+b_total chlorophyll; Gs_stomatal conductance; DIo/CSo_dissipated energy flux per cross section (CS) at t=0;ETo/CSo_electron transport flux per CS at t=0; ETR_electron transport rate of PSII; Fo_minimum fluorescence; Fm_maximum fluorescence; Fv_variable fluorescence; Fv/Fm_maximum quantum efficiency of PSII photochemistry; $\mathrm{H}_{2} \mathrm{O}_{2}$ hydrogen peroxide; MDA_malondialdehyde; ${ }_{2}{ }^{-}{ }^{-}$_superoxide anion radical; Pb_lead; Pn_net photosynthesis; POD_peroxidase; PSII_photosystem II; RC/CSo_amount of active PSII RCs per CS at t $=0$; ROS_reactive oxygen species; $\mathrm{SOD}_{-}$superoxide dismutase; $\mathrm{Tr}_{-}$transpiration rate; $\mathrm{TRo} / \mathrm{CSO}_{-}$trapped energy flux per CS at $\mathrm{t}=0$.

\section{Introduction}

Heavy metal contamination is a primary ecological issue in terms of human health, and lead $(\mathrm{Pb})$ has become a major contaminant that readily accumulates in soils and sediments. Lead toxicity to plants has been widely investigated (Jiang et al., 2014; Cha-Um et al., 2009; Sharma et al., 2005). Pb is not an essential element for plants, but it can be absorbed by the roots of crop and transported to shoots, and enter the food chain. $\mathrm{Pb}$ toxicity in plants is associated with negative effects on nutrient uptake, photosynthesis and anti-oxidant enzymes (Bharwana et al., 2014a; 2014b; Wang et al., 2011; Pourrut et al., 2011; Sengar et al., 2008). Photosynthetic efficiency, specifically for PSII behavior, has been widely assessed by using chlorophyll a fluorescence, which improved our understanding of the photosynthetic process. This technique is direct, non-destructive, highly sensitive, and reliable (Cuchiara et al., 2013; Yang et al., 2012; Buonasera et al., 2011; Mehta et al., 2010; Rohácek et al., 2002) and makes it possible to exploit the energy absorption of the pigments, the capture of an exciton, and the subsequent electron transport (Cuchiara et al., 2013; Yusuf et al., 2010; Krause and Weis,
1991). In observing the measured fluorescence transient (OJIP) by using a JIP-Test (Strasser et al., 1995; Strasser et al., 1998), it becomes possible to quantify the flux of energy through the photosystems, which is used to evaluate PSII operation during the photosynthetic performance of plants (Strasser et al., 2004; Tsimilli-Michael et al., 2008).

ROS such as $\mathrm{O}_{2} .^{-}, \mathrm{H}_{2} \mathrm{O}_{2}$ and $\mathrm{HO}^{-}$were overproduced as a consequence of the phytotoxicity of $\mathrm{Pb}$ (Bharwana et al.,2014a; 2014b; Reddy et al.,2005). MDA is widely used to evaluate the severity and degree of plant sensitivity to ROS (Shakoor et al., 2014). High proline contents may protect plants from environmental stress. Higher activities of antioxidant enzymes, such as SOD, POD, CAT and APX, and higher proline contents are associated with a higher tolerance to abiotic stress in most plants (Cha-Um et al., 2009; Lamhamdi et al., 2011; Verma et al., 2003; Huang et al., 2014). Longan is a famous and delicious fruit in subtropical areas, and it is primarily grown in South China (Qiu, 2014). Longan leaf has been traditionally used as a folklore medicine. It is also one of the major foreign exchange-earning crops in south China because of its high 
Table 1. The distribution of lead in different parts of longan seedlings. Values are means \pm SD $(n=3)$. Values followed by different letters indicating significant difference between treatments $(\mathrm{p} \leq 0.05)$.

\begin{tabular}{lccc}
\hline $\begin{array}{l}\text { Pb levels } \\
\left(\mathrm{mg} \mathrm{L}^{-1}\right)\end{array}$ & $\begin{array}{c}\mathrm{Pb} \text { concentration in roots } \\
\left(\mathrm{mg} \mathrm{kg}^{-1}\right)\end{array}$ & $\begin{array}{c}\text { Pb concentration in stem } \\
\left(\mathrm{mg} \mathrm{kg}^{-1}\right)\end{array}$ & $\begin{array}{c}\text { Pb concentration in leaves } \\
\left(\mathrm{mg} \mathrm{kg}^{-1}\right)\end{array}$ \\
\hline 0 & $10.51 \pm 1.33 \mathrm{e}$ & $4.28 \pm 0.31 \mathrm{c}$ & $1.12 \pm 0.19 \mathrm{~d}$ \\
100 & $82.87 \pm 9.25 \mathrm{e}$ & $11.50 \pm 1.28 \mathrm{c}$ & $1.89 \pm 0.16 \mathrm{c}$ \\
200 & $265.12 \pm 26.58 \mathrm{~d}$ & $15.67 \pm 1.12 \mathrm{c}$ & $2.35 \pm 0.23 \mathrm{c}$ \\
400 & $589.60 \pm 46.53 \mathrm{c}$ & $27.23 \pm 3.07 \mathrm{c}$ & $4.33 \pm 0.20 \mathrm{~b}$ \\
600 & $683.19 \pm 37.47 \mathrm{bc}$ & $103.80 \pm 11.44 \mathrm{~b}$ & $4.76 \pm 0.27 \mathrm{ab}$ \\
800 & $757.38 \pm 58.77 \mathrm{~b}$ & $168.50 \pm 17.79 \mathrm{a}$ & $4.90 \pm 0.35 \mathrm{ab}$ \\
1000 & $859.13 \pm 35.62 \mathrm{a}$ & $195.40 \pm 15.34 \mathrm{a}$ & $5.12 \pm 0.24 \mathrm{a}$ \\
\hline
\end{tabular}

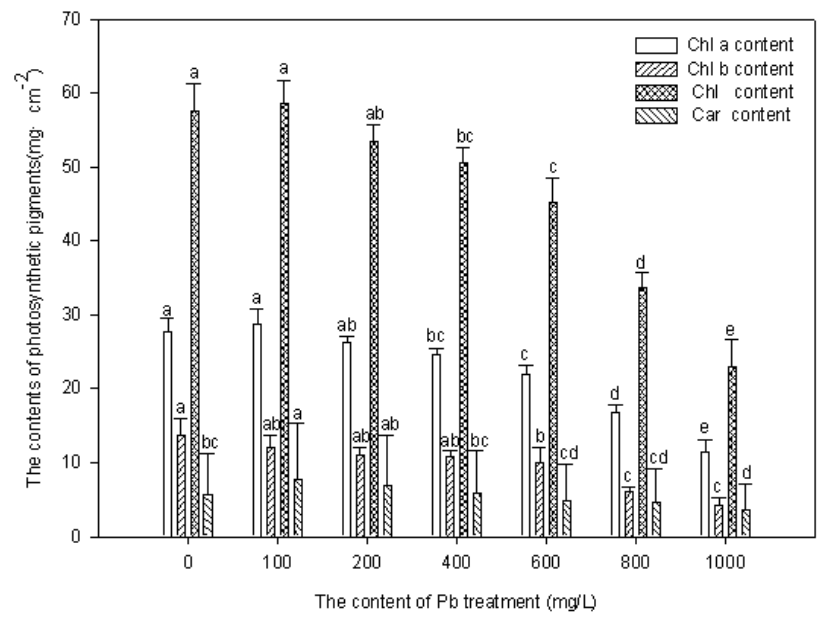

Fig 1. The effect of different $\mathrm{Pb}$ concentrations on mean $\pm \mathrm{SD}(n=5)$ photosynthetic pigments in $D$. longan leaves. Different letters indicate significant differences between treatments $(\mathrm{p} \leq 0.05)$.

Table 2. The dry biomass in leaf, stem and root of longan seedlings under Pb stress. Values are means \pm SD ( $n=3$ ). Values followed by different letters indicating significant difference between treatments $(\mathrm{p} \leq 0.05)$.

\begin{tabular}{lcccc}
\hline $\begin{array}{l}\text { Pb levels } \\
\left(\mathrm{mg} \mathrm{L}^{-1}\right)\end{array}$ & $\begin{array}{c}\text { Root dry weight Plant } \\
(\mathrm{g})\end{array}$ & $\begin{array}{c}\text { Stem dry weight } \\
\text { Plant }^{-1}(\mathrm{~g})\end{array}$ & $\begin{array}{c}\text { Leaf dry weight Plant }^{-1} \\
(\mathrm{~g})\end{array}$ & $\begin{array}{c}\text { Plant dry weight Plant }^{-1} \\
(\mathrm{~g})\end{array}$ \\
\hline 0 & $6.98 \pm 0.37 \mathrm{~cd}$ & $3.27 \pm 0.23 \mathrm{a}$ & $3.36 \pm 0.24 \mathrm{a}$ & $13.60 \pm 0.75 \mathrm{bc}$ \\
100 & $7.60 \pm 0.33 \mathrm{c}$ & $3.20 \pm 0.19 \mathrm{a}$ & $2.88 \pm 0.23 \mathrm{ab}$ & $13.68 \pm 0.28 \mathrm{bc}$ \\
200 & $9.64 \pm 0.43 \mathrm{a}$ & $3.41 \pm 0.25 \mathrm{a}$ & $2.80 \pm 0.20 \mathrm{~b}$ & $15.85 \pm 0.53 \mathrm{a}$ \\
400 & $8.96 \pm 0.37 \mathrm{ab}$ & $3.26 \pm 0.19 \mathrm{a}$ & $2.60 \pm 0.25 \mathrm{~b}$ & $14.81 \pm 0.46 \mathrm{ab}$ \\
600 & $8.64 \pm 0.28 \mathrm{~b}$ & $2.65 \pm 0.19 \mathrm{~b}$ & $1.92 \pm 0.22 \mathrm{c}$ & $13.21 \pm 0.62 \mathrm{c}$ \\
800 & $6.47 \pm 0.34 \mathrm{~d}$ & $2.52 \pm 0.23 \mathrm{~b}$ & $1.64 \pm 0.16 \mathrm{c}$ & $10.63 \pm 0.61 \mathrm{~d}$ \\
1000 & $5.40 \pm 0.37 \mathrm{e}$ & $2.45 \pm 0.23 \mathrm{~b}$ & $1.48 \pm 0.21 \mathrm{c}$ & $9.33 \pm 0.43 \mathrm{e}$ \\
\hline
\end{tabular}

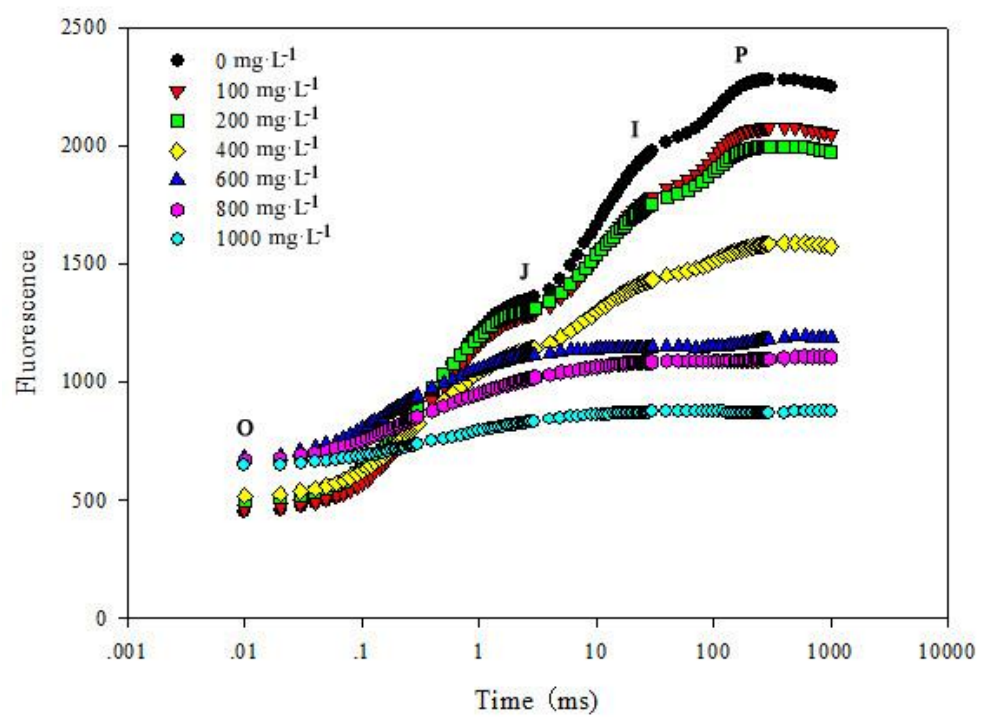

Fig 2. Effects of lead $(\mathrm{Pb})$ treatments on the high irradiance actinic-light-induced chlorophyll a fluorescence (OJIP) transient of dark-adapted D. longan leaves plotted on a logarithmic time scale $(0.01 \mathrm{~ms}$ to $1 \mathrm{~s})$. 
quality. Increased fruit demand can be achieved by increasing production areas. However, this could lead the production of $D$. longan in $\mathrm{Pb}$-affected regions. To our knowledge, little is known about the $\mathrm{Pb}$ tolerance mechanism of longan plants. Therefore, the specific objective of this study was to explore $D$. longan plant tolerance to $\mathrm{Pb}$ stress, special changes in chlorophyll a fluorescence, gas exchange traits, pigment contents, soluble protein, anti-oxidant enzymes, MDA and non-enzymatic antioxidants.

\section{Results}

\section{$P b$ distribution in plants and the plant growth}

The roots of the longan seedlings had the highest $\mathrm{Pb}$ levels followed by the stems, and the leaves showed the lowest amounts of $\mathrm{Pb}$. Compared with control. irrespective of the concentration of $\mathrm{Pb}$ applied, $\mathrm{Pb}$-treated plants exhibited increased $\mathrm{Pb}$ concentrations in the leaves, stems and roots (Table 1) and decreased leaf dry mass (Table 2). The leaf dry weights were significantly less at $200 \mathrm{mg}$. $\mathrm{L}^{-1} \mathrm{~Pb}$ compared with control (Table 2), but the root dry mass with $200 \mathrm{mg} . \mathrm{L}^{-1}$ $\mathrm{Pb}$ treatment was significantly higher than that of the control plants (Table 2). However, the dry mass of root decreased when the plants were treated with $\mathrm{Pb}$ concentrations over 600 $\mathrm{mg} \mathrm{L}^{-1}$ (Table 2).

\section{Chlorophyll contents}

The photosynthetic pigment (Chl a, Chl b, Chl a+b and Car) contents of longan leaves were noticeably decreased with the increasing $\mathrm{Pb}$ concentrations (Fig. 1). The $\mathrm{Chl} \mathrm{a,} \mathrm{Chl} \mathrm{b}$ and $\mathrm{Chl}$ $a+b$ and Car contents were not significantly affected by the presence of $\mathrm{Pb}$ until reaching $400 \mathrm{mg} \mathrm{L}^{-1} \mathrm{~Pb}$, whereas their contents in the $1000 \mathrm{mg} \cdot \mathrm{L}^{-1} \mathrm{~Pb}$ treatment were $59 \%, 70 \%, 60 \%$ and $37 \%$ lower compared with control, respectively. $\mathrm{Pb}$ treatment at $800 \mathrm{mg} \mathrm{L}^{-1}$ showed significant increase in the Chl $\mathrm{a} / \mathrm{b}$ ratio.

\section{Chlorophyll a fluorescence}

Both $\mathrm{Pb}$-treated leaves and control showed a typical polyphasic rise of OJIP transient, including $\mathrm{O}, \mathrm{J}, \mathrm{I}$, and $\mathrm{P}$ phases. $\mathrm{Pb}$ treated leaves resulted in a decrease at the $\mathrm{J}, \mathrm{I}$ and P-step. However, $\mathrm{Pb}$ treatments over $600 \mathrm{mg} . \mathrm{L}^{-1}$ showed dramatic increases at the O-step (Fig.2).The Fo for leaves receiving $600 \mathrm{mgL}^{-1} \mathrm{~Pb}$ treatments increased significantly, whereas the Fm, Fv, Fv/Fm, TRo/CSo, ETo/CSo, DIo/CSo, and $\mathrm{RC} / \mathrm{CS}$ o significantly decreased in comparison with control. However, these parameters had no significant differences in treatments of $0-200 \mathrm{mg} \mathrm{L}^{-1} \mathrm{~Pb}$ (Table 3).

\section{Gas exchange}

$\mathrm{Pb}$ stress led to a continuous decline in $\mathrm{Pn}, \mathrm{Tr}$, and Gs compared with control. Higher $\mathrm{Pb}$ stress $(800$ and 1000 mg. $\mathrm{L}^{-1}$ ) led to the dramatic reduction in $\mathrm{Pn}$, Tr, and Gs. The plants that were grown under control conditions exhibited the maximum values for $\mathrm{Pn}$, Tr, and Gs compared with other treatments (Table 4).

\section{Superoxide anion radical, hydrogen peroxide, MDA and} free proline content

$\mathrm{Pb}$ treatment continuously stimulated the superoxide anion radical, hydrogen peroxide, MDA accumulation and free proline content in $\mathrm{Pb}$-treated longan leaves, with a higher increase in more Pb-stressed plants. The $400 \mathrm{mg} . \mathrm{L}^{-1} \mathrm{~Pb}$ treatment showed a significant increase in the superoxide anion radical, hydrogen peroxide, MDA level and free proline content, whereas nearly $3.7,3.2,1.6$ and 14.5 times enhancement in the superoxide anion radical, hydrogen peroxide, MDA level and free proline content were observed, respectively, in the leaves of seedlings receiving a 1000 mg. $\mathrm{L}^{-1} \mathrm{~Pb}$ treatment compared with control (Table 5).

\section{Activity of antioxidant enzymes}

The antioxidant enzyme (SOD, POD, CAT, and APX) activities in the leaves responded variably to different $\mathrm{Pb}$ treatments (Table 6). The SOD activity was consistently increased with increased $\mathrm{Pb}$ concentrations. The higher the concentration was, the greater the SOD activity. The CAT and APX activities were initially enhanced and then decreased with increasing $\mathrm{Pb}$ concentrations. The activities reached a peak at $600 \mathrm{mg} \mathrm{L}^{-1}$ and then subsequently dropped. However, the POD activity was reduced with increasing $\mathrm{Pb}$ levels and remained significantly lower than that of the control plants under any $\mathrm{Pb}$ level. The total soluble protein contents of leaves were significantly inhibited by increasing $\mathrm{Pb}$ concentrations.

\section{Pearson correlation coefficients among qualitative and quantitative traits in D. longan plants}

Longan plant growth parameters such as the leaf dry mass and Pn varied markedly and were positively correlated with the Chl content, but they were negatively correlated with the SOD activity, soluble protein and free proline contents (Table 7). A significantly negative correlation between $\mathrm{Pb}$ uptake and $\mathrm{Chl}$ content, $\mathrm{Chl}$ a fluorescence parameters and gas exchange parameters was observed. MDA, $O_{2} .^{-}$, and $\mathrm{H}_{2} \mathrm{O}_{2}$ had significantly negative correlations with the Chl content, $\mathrm{Chl}$ a fluorescence parameters, and net photosynthesis.

\section{Discussion}

A common effect of $\mathrm{Pb}$ stress on plants is the reduction of growth and yield, but the effects are more pronounced at higher Pb levels (Sharma et al., 2005; Bharwana et al., 2014a; 2014b; Sengar et al., 2008). Our data showed that increasing the dose of $\mathrm{Pb}$ treatments $\left(0-1000 \mathrm{mg} \mathrm{L}^{-1}\right)$ markedly affected the growth of $D$. longan plants in terms of leaf, stem and root dry weights. This finding matched the $\mathrm{Pb}$-induced alterations in soluble proteins, chlorophyll content, Pn, and Tr. However, no significant difference was observed between the control plants and those grown in the presence of $100 \mathrm{mg} \mathrm{L}^{-1} \mathrm{~Pb}$, suggesting that $D$. longan plants are tolerant to mild stress of $\mathrm{Pb}$

Plant growth relies on photosynthesis, and therefore, environmental perturbations that affect growth will also affect photosynthesis (Sharma et al., 2005; Bharwana et al., 2014a; 2014b; Sengar et al., 2008). In the present study, the decline of photosynthesis in plants at low $\mathrm{Pb}$ levels might be related to stomatal factors such as stomatal closure and depression in carbon uptake (Table 4). At high Pb level, the decline might be related to non-stomatal factors, namely the reduction in the pigment content (Fig. 1), the reduced $\mathrm{Pb}$-induced oxidative stress (Table 5) and the inhibition of photochemical processes (Table 3). In response to the decline in leaf turgor pressure, stomatal closure minimized water loss through transpiration, resulting in lower transpiration rates (Table 4). Hence, under mild stress, a small decline in stomatal conductance (Gs) may 
Table 3. Effects of different concentrations of $\mathrm{Pb}$ on parameters of Fo,Fm,Fv ,Fv/Fm,TRo/CSo,ETo/CSo,DIo/CSo and RC/CSo of Dimocarpus longan Lour.Values are means $\pm \mathrm{SD}$ ( $\mathrm{n}=6-14$ ).

Values followed by different letters indicating significant difference between treatments $(p \leq 0.05)$.

\begin{tabular}{|c|c|c|c|c|c|c|c|c|}
\hline $\begin{array}{l}\text { Pb levels } \\
\left(\mathrm{mgL}^{-1}\right)\end{array}$ & Fo & $\mathrm{Fm}$ & Fv & $\mathrm{Fv} / \mathrm{Fm}$ & TRo/CSo & ETo/CSo & DIo/CSo & RC/CSo \\
\hline 0 & $414.00 \pm 34.02 \mathrm{~b}$ & $2279.40 \pm 78.33 a$ & $1865.40 \pm 54.19 \mathrm{a}$ & $0.819 \pm 0.011 \mathrm{a}$ & $338.58 \pm 23.89 \mathrm{a}$ & $171.90 \pm 6.11 \mathrm{a}$ & $75.42 \pm 10.31 \mathrm{c}$ & $172.35 \pm 6.45 a$ \\
\hline 100 & $430.67 \pm 41.07 b$ & $2078.00 \pm 339.42 \mathrm{ab}$ & $1647.33 \pm 376.92 \mathrm{ab}$ & $0.783 \pm 0.070 \mathrm{ab}$ & $335.06 \pm 12.42 \mathrm{a}$ & $162.02 \pm 16.59 \mathrm{a}$ & $95.61 \pm 42.46 b c$ & $171.71 \pm 2.86 \mathrm{a}$ \\
\hline 200 & $468.14 \pm 82.03 b$ & $2001.64 \pm 413.38 \mathrm{ab}$ & $1533.50 \pm 456.95 \mathrm{ab}$ & $0.746 \pm 0.119 \mathrm{ab}$ & $342.32 \pm 46.51 \mathrm{a}$ & $154.07 \pm 34.30 \mathrm{a}$ & $125.82 \pm 84.11 b c$ & $163.44 \pm 23.20 \mathrm{a}$ \\
\hline 400 & $497.58 \pm 94.33 b$ & $1592.50 \pm 563.32 \mathrm{bc}$ & $1094.92 \pm 630.94 b$ & $0.620 \pm 0.210 \mathrm{~b}$ & $295.78 \pm 77.16 \mathrm{a}$ & $116.67 \pm 49.13 b$ & $201.8 \pm 134.44 b$ & $141.44 \pm 32.97 \mathrm{ab}$ \\
\hline 600 & $680.75 \pm 111.69 a$ & $1194.0 \pm 423.070 \mathrm{~cd}$ & $513.25 \pm 318.67 \mathrm{c}$ & $0.402 \pm 0.104 \mathrm{c}$ & $280.89 \pm 116.09 \mathrm{a}$ & $54.58 \mathrm{c} \pm 6.88$ & $399.86 \pm 48.47 \mathrm{a}$ & $118.76 \pm 31.70 b c$ \\
\hline 800 & $669.89 \pm 100.81 \mathrm{a}$ & $1114.33 \pm 319.62 \mathrm{~cd}$ & $444.44 \pm 280.22 \mathrm{c}$ & $0.361 \pm 0.157 \mathrm{c}$ & $245.09 \pm 108.43 \mathrm{ab}$ & $64.64 \pm 23.08 \mathrm{c}$ & $424.80 \pm 102.82 \mathrm{a}$ & $114.84 \pm 38.00 \mathrm{bc}$ \\
\hline 1000 & $624.14 \pm 123.73 \mathrm{a}$ & $882.25 \pm 173.29 \mathrm{~d}$ & $235.00 \pm 104.23 \mathrm{c}$ & $0.259 \pm 0.080 \mathrm{c}$ & $167.13 \pm 60.53 b$ & $44.37 \pm 16.44 \mathrm{c}$ & $480.12 \pm 101.66 a$ & $84.37 \pm 24.73 c$ \\
\hline
\end{tabular}

Table 4. Changes in gas exchange under varying $\mathrm{Pb}$ conditions. Values in the table are mean $\pm \mathrm{SD}(\mathrm{n}=6)$. Values followed by the different letter indicate significant difference between treatments $(\mathrm{p} \leq 0.05)$.

\begin{tabular}{lccc}
\hline $\begin{array}{l}\text { Pb levels } \\
\left(\mathrm{mg} \mathrm{L}^{-1}\right)\end{array}$ & $\begin{array}{c}\mathrm{Pn} \\
\left(\mu \mathrm{mol} \mathrm{CO} \mathrm{m}^{-2} \mathrm{~s}^{-1}\right)\end{array}$ & $\begin{array}{c}\mathrm{Tr} \\
\left(\mathrm{mmol} \mathrm{H}_{2} \mathrm{O}_{2} \mathrm{~m}^{-2} \mathrm{~s}^{-1}\right)\end{array}$ & $\begin{array}{c}\mathrm{Gs} \\
\left(\mathrm{mmoL} \mathrm{H}_{2} \mathrm{O}_{2} \mathrm{~m}^{-2} \mathrm{~s}^{-1}\right)\end{array}$ \\
\hline 0 & $2.61 \pm 0.17 \mathrm{a}$ & $1.02 \pm 0.05 \mathrm{a}$ & $30.05 \pm 1.44 \mathrm{a}$ \\
100 & $2.48 \pm 0.18 \mathrm{a}$ & $1.08 \pm 0.04 \mathrm{a}$ & $28.35 \pm 1.33 \mathrm{~b}$ \\
200 & $2.11 \pm 0.15 \mathrm{~b}$ & $1.03 \pm 0.06 \mathrm{a}$ & $22.45 \pm 1.26 \mathrm{c}$ \\
400 & $2.00 \pm 0.14 \mathrm{~b}$ & $0.92 \pm 0.07 \mathrm{~b}$ & $22.73 \pm 1.40 \mathrm{c}$ \\
600 & $1.79 \pm 0.11 \mathrm{c}$ & $0.66 \pm 0.05 \mathrm{c}$ & $19.48 \pm 1.37 \mathrm{~d}$ \\
800 & $0.34 \pm 0.13 \mathrm{~d}$ & $0.26 \pm 0.03 \mathrm{~d}$ & $6.18 \pm 0.83 \mathrm{e}$ \\
1000 & $0.32 \pm 0.13 \mathrm{~d}$ & $0.20 \pm 0.02 \mathrm{e}$ & $4.78 \pm 0.80 \mathrm{e}$ \\
\hline
\end{tabular}

Table 5. The effect of different $\mathrm{Pb}$ concentration on contents of superoxide anion radical, hydrogen peroxide, MDA and free proline. Values in the table are mean $\pm \mathrm{SD}$ ( $\mathrm{n}=3$ ). Values followed by the different letter indicate significant difference between treatments $(\mathrm{p} \leq 0.05)$.

\begin{tabular}{lcccc}
\hline $\begin{array}{l}\mathrm{Pb} \text { levels } \\
\left(\mathrm{mg} \mathrm{L}^{-1}\right)\end{array}$ & $\begin{array}{c}\mathrm{O}_{2} \cdot{ }^{-} \\
\left(\Delta \mathrm{OD} 580 \mathrm{~m}^{-2} \mathrm{~s}^{-1}\right)\end{array}$ & $\begin{array}{c}\mathrm{H}_{2} \mathrm{O}_{2} \\
\left(\mathrm{nmol} \mathrm{mg}^{-1} \text { protein }\right)\end{array}$ & $\begin{array}{c}\text { MDA content } \\
\left(\mathrm{mmol} \mathrm{g}^{-1} \mathrm{FW}\right)\end{array}$ & $\begin{array}{c}\text { Free proline content } \\
\left(\mathrm{mg} \mathrm{g}^{-1} \mathrm{FW}\right)\end{array}$ \\
\hline 0 & $0.447 \pm 0.069 \mathrm{c}$ & $1.374 \pm 0.225 \mathrm{~d}$ & $21.011 \pm 1.275 \mathrm{e}$ & $0.075 \pm 0.029 \mathrm{~d}$ \\
100 & $0.568 \pm 0.072 \mathrm{c}$ & $1.420 \pm 0.201 \mathrm{~d}$ & $21.804 \mathrm{e} \pm 0.925$ & $0.076 \pm 0.016 \mathrm{~d}$ \\
200 & $0.725 \pm 0.089 \mathrm{c}$ & $1.895 \pm 0.313 \mathrm{~cd}$ & $22.482 \pm 0.824 \mathrm{e}$ & $0.145 \pm 0044 \mathrm{~d}$ \\
400 & $1.119 \pm 0.106 \mathrm{~b}$ & $2.273 \pm 0.371 \mathrm{~cd}$ & $27.846 \pm 1.178 \mathrm{~d}$ & $0.510 \pm 0.046 \mathrm{c}$ \\
600 & $1.292 \pm 0.121 \mathrm{~b}$ & $2.536 \pm 0.301 \mathrm{c}$ & $31.441 \pm 1.135 \mathrm{c}$ & $0.747 \mathrm{~b} \pm 0.044$ \\
800 & $2.067 \pm 0.106 \mathrm{a}$ & $4.489 \pm 0.344 \mathrm{~b}$ & $35.856 \pm 1.012 \mathrm{~b}$ & $0.701 \pm 0.084 \mathrm{~b}$ \\
1000 & $2.117 \pm 0.162 \mathrm{a}$ & $5.702 \pm 0.495 \mathrm{a}$ & $55.458 \pm 1.527 \mathrm{a}$ & $1.160 \pm 0.084 \mathrm{a}$ \\
\hline
\end{tabular}


Table 6. The effect of different $\mathrm{Pb}$ concentrations on the activities of SOD, POD, CAT and APX, and the content of soluble protein. Values are means \pm SD ( $\mathrm{n}=3-6$ ). Values followed by different letters indicating significant difference between treatments $(\mathrm{p} \leq 0.05)$.

\begin{tabular}{|c|c|c|c|c|c|}
\hline $\begin{array}{l}\text { Pb levels } \\
\left(\mathrm{mg} \mathrm{L}^{-1}\right)\end{array}$ & $\begin{array}{l}\text { SOD activity } \\
\quad\left(\text { units } \mathrm{g}^{-1} \mathrm{FW} \mathrm{s}^{-1} \text { ) }\right.\end{array}$ & $\begin{array}{l}\text { POD activity } \\
\left(\triangle \mathrm{OD} 470 \mathrm{~g}^{-1} \mathrm{FW}\right)\end{array}$ & $\begin{array}{l}\text { CAT activity } \\
\left(\text { nmol } \cdot \mathrm{g}^{-1} \mathrm{FW} \cdot \mathrm{s}^{-1}\right)\end{array}$ & $\begin{array}{l}\text { APX activity } \\
\left(\text { nmol } \cdot \mathrm{g}^{-1} \mathrm{FW} \cdot \mathrm{s}^{-1}\right)\end{array}$ & $\frac{\text { Soluble protein content }}{\left(\mathrm{mg} \cdot \mathrm{g}^{-1} \mathrm{FW}\right)}$ \\
\hline 0 & $17.99 \pm 1.23 \mathrm{c}$ & $51.84 \pm 1.47 \mathrm{a}$ & $11.17 \pm 1.21 \mathrm{~d}$ & $421.16 \pm 28.46 c$ & $17.05 \pm 0.53 a$ \\
\hline 100 & $16.50 \pm 1.22 \mathrm{c}$ & $44.48 \pm 1.69 b$ & $13.95 \pm 0.96 c$ & $425.40 \pm 32.61 \mathrm{c}$ & $16.28 \pm 0.33 \mathrm{a}$ \\
\hline 200 & $21.89 \pm 1.50 \mathrm{~b}$ & $40.64 \pm 1.15 b c$ & $14.06 \pm 1.12 \mathrm{c}$ & $555.56 \pm 32.22 b$ & $10.51 \pm 0.56 \mathrm{~b}$ \\
\hline 400 & $23.87 \pm 1.32 b$ & $38.48 \pm 1.84 \mathrm{~cd}$ & $19.89 \pm 0.96 b$ & $681.48 \pm 33.95 a$ & $6.23 \pm 0.43 c$ \\
\hline 600 & $24.12 \pm 0.93 b$ & $34.99 \pm 1.12 d$ & $23.31 \pm 1.58 \mathrm{a}$ & $746.83 \pm 33.23 a$ & $5.59 \pm 0.34 \mathrm{~cd}$ \\
\hline 800 & $27.48 \pm 0.78 \mathrm{a}$ & $26.88 \pm 1.60 \mathrm{e}$ & $5.11 \pm 1.32 \mathrm{e}$ & $445.50 \pm 38.14 c$ & $4.83 \pm 0.32 \mathrm{de}$ \\
\hline 1000 & $27.71 \pm 0.85 a$ & $23.89 \pm 1.76 \mathrm{e}$ & $1.50 \pm 0.73 \mathrm{f}$ & $329.10 \pm 29.50 \mathrm{~d}$ & $4.06 \pm 0.34 \mathrm{e}$ \\
\hline
\end{tabular}

Table 7. Pearson correlation among different photosynthetic parameters and antioxidant enzyme activities in D.longan leaves under Pb stress

\begin{tabular}{|c|c|c|c|c|c|c|c|c|c|c|c|c|c|c|c|c|c|c|c|c|}
\hline Parameter & Protein & SOD & POD & CAT & APX & $\mathrm{H}_{2} \mathrm{O}_{2}$ & $\mathrm{O}_{2} .^{-}$ & MDA & Proline & Fo & $\mathrm{Fm}$ & $\mathrm{Fv}$ & $\mathrm{Fv} / \mathrm{Fm}$ & TRo/CSo & ETo/CSo & DIo/CSo & RC/CSo & $\mathrm{Chl}$ & $\mathrm{Pn}$ & Leaf dry mass \\
\hline $\mathrm{Pb}_{\text {leaf }}$ & $-.973^{* *}$ & $.923^{* *}$ & $-.912^{* * *}$ & -.123 & .233 & $.789^{*}$ & $.900^{* *}$ & $.767^{*}$ & $.919^{* *}$ & $.897^{* *}$ & $-.967^{* *}$ & $-.963^{* *}$ & $-.933^{* *}$ & $-.819^{*}$ & $-.949^{* *}$ & $.921^{* *}$ & $-.918^{* * *}$ & $-.822^{*}$ & $-.811^{*}$ & $-.927^{* *}$ \\
\hline Protein & 1 & $-.962^{* *}$ & $.900^{* *}$ & .117 & -.277 & $-.770^{*}$ & $-.871^{*}$ & -.733 & $-.879^{* *}$ & $-.860^{*}$ & $.926^{* *}$ & $.922^{* *}$ & $.889^{* *}$ & $.770^{*}$ & $.903^{* *}$ & $-.877^{* *}$ & $.884^{* *}$ & $.805^{*}$ & $.797^{*}$ & $.886^{* *}$ \\
\hline SOD & & 1 & $-.927^{* *}$ & -.354 & .057 & $.876^{* *}$ & $.937^{* *}$ & $.802^{*}$ & $.888^{* *}$ & $.848^{*}$ & $-.921^{* *}$ & $-.917^{* *}$ & $-.907^{* *}$ & $-.838^{*}$ & $-.891^{* *}$ & $.899^{* *}$ & $-.911^{* *}$ & $-.897^{* *}$ & $-.903^{* *}$ & $-.897^{* *}$ \\
\hline POD & & & 1 & 0.456 & 0.113 & $-.934^{* *}$ & $-.970^{* *}$ & $-.876^{* *}$ & $-.906^{* *}$ & $-.855^{*}$ & $.954^{* *}$ & $.948^{* *}$ & $.943^{* *}$ & $.901^{* *}$ & $.910^{* *}$ & $-.932^{* *}$ & $.936^{* *}$ & $.941^{* *}$ & $.952^{* *}$ & $.976^{* *}$ \\
\hline CAT & & & & 1 & $.906^{* *}$ & -.693 & -.532 & -.601 & -.346 & -.148 & .299 & .282 & .358 & .586 & .226 & -.348 & .402 & .630 & .662 & .371 \\
\hline APX & & & & & 1 & -.387 & -.184 & -.350 & -.039 & .187 & -.037 & -.056 & .030 & .315 & -.101 & -.019 & .081 & .314 & .325 & .045 \\
\hline $\mathrm{H}_{2} \mathrm{O}_{2}$ & & & & & & 1 & $.963^{* *}$ & $.956^{* *}$ & $.902^{* *}$ & .744 & $-.889^{* *}$ & $-.877^{* *}$ & $-.907^{* *}$ & $-.970^{* *}$ & $-.841^{*}$ & $.893^{* *}$ & $-.932^{* *}$ & $-.994^{* *}$ & $-.977^{* *}$ & $-.902^{* *}$ \\
\hline$O_{2} \cdot-$ & & & & & & & 1 & $.888^{* *}$ & $.919^{* * *}$ & $.862^{*}$ & $-.954^{* *}$ & $-.948^{* *}$ & $-.957^{* *}$ & $-.933^{* *}$ & $-.917^{* *}$ & $.949^{* *}$ & $-.949^{* *}$ & $-.967^{* *}$ & $-.982^{* *}$ & $-.959^{* *}$ \\
\hline MDA & & & & & & & & 1 & $.940^{* *}$ & .690 & $-.875^{* *}$ & $-.857^{*}$ & $-.891^{* *}$ & $-.989^{* *}$ & $-.837^{*}$ & $.870^{*}$ & $-.944^{* *}$ & $-.965^{* *}$ & $-.878^{* *}$ & $-.861^{*}$ \\
\hline Proline & & & & & & & & & 1 & $.852^{*}$ & $-.971^{* *}$ & $-.963^{* *}$ & $-.971^{* *}$ & $-.958^{* *}$ & $-.960^{* *}$ & $.957^{* *}$ & $-.994^{* *}$ & $-.936^{* *}$ & $-.856^{*}$ & $-.930^{* *}$ \\
\hline Fo & & & & & & & & & & 1 & $-.931^{* *}$ & $-.950^{* *}$ & $-.940^{* *}$ & -.744 & $-.962^{* *}$ & $.956^{* *}$ & $-.877^{* *}$ & $-.793^{*}$ & $-.798^{*}$ & $-.935^{* *}$ \\
\hline $\mathrm{Fm}$ & & & & & & & & & & & 1 & $.998^{* * *}$ & $.993^{* *}$ & $.913^{* *}$ & $.989^{* * *}$ & $-.986^{* *}$ & $.981^{* * *}$ & $.920^{* * *}$ & $.892^{* * *}$ & $.983^{* *}$ \\
\hline $\mathrm{Fv}$ & & & & & & & & & & & & 1 & $.994^{* *}$ & $.897^{* *}$ & $.994^{* *}$ & $-.991^{* *}$ & $.975^{* *}$ & $.911^{* *}$ & $.886^{* *}$ & $.985^{* *}$ \\
\hline $\mathrm{Fv} / \mathrm{Fm}$ & & & & & & & & & & & & & 1 & $.926^{* *}$ & $.990^{* * *}$ & $-.998^{* *}$ & $.986^{* *}$ & $.938^{* *}$ & $.906^{* *}$ & $.983^{* *}$ \\
\hline TRo/CSo & & & & & & & & & & & & & & 1 & $.876^{* *}$ & $-.906^{* *}$ & $.964^{* *}$ & $.977^{* *}$ & $.912^{* *}$ & $.894^{* *}$ \\
\hline ETo/CSo & & & & & & & & & & & & & & & 1 & $-.991^{* *}$ & $.968^{* *}$ & $.884^{* *}$ & $.845^{*}$ & $.968^{* *}$ \\
\hline DIo/CSo & & & & & & & & & & & & & & & & 1 & $-.976^{* *}$ & $-.927^{* *}$ & $-.899^{* *}$ & $-.981^{* *}$ \\
\hline RC/CSo & & & & & & & & & & & & & & & & & 1 & $.961^{* *}$ & $.901^{* *}$ & $.956^{* *}$ \\
\hline Chl & & & & & & & & & & & & & & & & & & 1 & $.967^{* *}$ & $.924^{* *}$ \\
\hline Pn & & & & & & & & & & & & & & & & & & & 1 & $.921^{* *}$ \\
\hline
\end{tabular}

* Correlation is significant at the 0.05 level (2-tailed).

** Correlation is significant at the 0.01 level (2-tailed). 
have protective effects against stress. This finding was confirmed in Jatropha curcas L. plants in response to $\mathrm{Pb}$ stress (Shu et al., 2012). At higher $\mathrm{Pb}$ levels, greater reductions in $\mathrm{Pn}, \mathrm{Tr}$ and Gs were observed (Table 4). This decrease in the $\mathrm{Pn}, \mathrm{Tr}$ and $\mathrm{Gs}$ at higher $\mathrm{Pb}$ was primarily caused by a reduction in the carboxylation rate that was out of proportion,arising from non-stomatal factors such as decreasing chlorophyll contents. Similar observation has been recorded in Populus cathayana plants that were exposed to lead and drought (Han et al., 2013).

During plant photosynthesis, the shift of energy through the PSII at the reaction center level and the excited cross-section level can be assessed by using the OJIP test (Strasser et al., 1995). The present study showed that Fm, Fv, Fv/Fm, TRo/CSo, ETo/CSo and RC/CSo were significantly decreased with the increased $\mathrm{Pb}$ treatments; by contrast, the $\mathrm{Fo}$ and DIo/CSo increased (Table 3). Lead decreased the Fv/Fm and altered the OJIP transient (Figure 2), indicating that photo-inhibition occurs in leaves that were exposed to $\mathrm{Pb}$. The reduction in the $\mathrm{Fv} / \mathrm{Fm}$ was caused by both the decline of Fm and the increase in $\mathrm{Fv}$ (Table 3). Because $\mathrm{Pb}$ treatment decreased the RC/CSo (Table 3), the increase in the Fo may have resulted from the inactivation of RC in PSII (Jiang et al., 2008; Yamane et al., 1997) and the accumulation of reduced QA (Jiang et al., 2008; Bukhov et al., 1990). Moreover, $\mathrm{ETo} / \mathrm{CSo}$ decreased to a greater extent in $400 \mathrm{mg} . \mathrm{L}^{-1}$ $\mathrm{Pb}$-treated leaves, indicating the re-oxidation of reduced QA via electron transport from PS II to PS I, which was likely caused by an over-reduction of the photo-system in response to $\mathrm{Pb}$ stress. The decline in the ETo/CSo suggested that the damage to the PS II acceptor side occurred in Pb-treated leaves. The present investigation showed that the Pn was significantly and positively correlated with PS II photochemistry and chlorophyll levels. However, ETo/CSo, TRo/CSo, RC/CSo, Fm, Fv, and Fv/Fm were significantly and negatively correlated with the SOD activity and free proline content (Table 7). Similar result was observed in cotton that was stressed by lead (Bharwana et al., 2014a; 2014b).

Lead stress leads to ROS overproduction, leading to oxidative destruction in plant cells (Shamsi et al., 2008; Asada, 1996; Pinho and Ladeiro, 2012; Apel and Hirt, 2004). Increases in MDA and $\mathrm{H}_{2} \mathrm{O}_{2}$ contents under $\mathrm{Pb}$ stress accounted for lipid peroxidation or plasma membrane damage, which in turn inhibited plant growth (Zhang et al., 2009). In our experiment, the MDA, $\mathrm{O}_{2}{ }^{-}$- and $\mathrm{H}_{2} \mathrm{O}_{2}$ contents showed continuous accumulation in leaves with increasing $\mathrm{Pb}$ stress (Table 5), suggesting that $\mathrm{Pb}$ stress actually induced the decline in PSII activity. Similar findings for $\mathrm{Pb}$-induced membrane lipid peroxidation by means of ROS were recorded by Shakoor et al. (2014) and Kanwal et al. (2014).

In our study, SOD activity was continuously enhanced with increased $\mathrm{Pb}$ stress, whereas APX and CAT activity were initially enhanced and subsequently decreased with increased $\mathrm{Pb}$ concentrations. This finding indicates that CAT and APX activity at lower $\mathrm{Pb}$ stress $\left(100-600 \mathrm{mg} \mathrm{L}^{-1} \mathrm{~Pb}\right)$ could quench $\mathrm{H}_{2} \mathrm{O}_{2}$ and protect the $D$. longan plants from oxidative injury, and the scavenging functions of CAT and APX were impaired under higher $\mathrm{Pb}$ stress $\left(800-1000 \mathrm{mg} \mathrm{L}^{-1} \mathrm{~Pb}\right.$ ). Nonetheless, cooperation from antioxidant enzymes is essential for the scavenging of ROS in plant cells. This finding indicated that the $\mathrm{O}_{2} \cdot{ }^{-}$scavenging was performed properly by the SOD and the combined action of CAT, APX, and POD converted the $\mathrm{H}_{2} \mathrm{O}_{2}$ to water. Obviously, lead influences the activity of antioxidative enzymes, which vary with the $\mathrm{Pb}$ levels.

The protein contents of leaves were significantly reduced at a stress level over $200 \mathrm{mg} \mathrm{L}^{-1} \mathrm{~Pb}$, which may result from the oxidative damage. Similar $\mathrm{Pb}$ effects have been documented in association with metal toxicity (Bharwana et al., 2014a; Gupta et al., 2009]). In this study, a progressive enhancement in proline was recorded with increasing $\mathrm{Pb}$ stress (Table 5), suggesting that elevated proline protected $D$. longan plants from oxidative stress, lipid peroxidation and cell damage, and the tolerance improved. A similar finding was recorded in Boehmeria nivea $\mathrm{L}$. in response to salt stress (Lamhamdi et al., 2011). Therefore, the free proline content combined with the $\mathrm{SOD}$ may play a key role in $\mathrm{D}$. longan tolerance to $\mathrm{Pb}$ stress.

\section{Materials and Methods}

\section{Plant materials and growth conditions}

Longan (Dimocarpus longan L. cv. Wulongling) seeds were provided by the Putian Institute of Pomology, Fujian Province, and they were germinated in pots filled with sand inside pots and then irrigated with nutrient solution according to Wang and Zhuang (1981). Twelve weeks after germination, uniform seedlings were selected and transplanted to pots filled with sand. Three seedlings per pot were grown in a net house in a natural photoperiod at Fujian Agriculture and Forestry University. Each pot was supplied with $250 \mathrm{ml}$ of nutrient solution every alternate day.

\section{$P b$ treatments}

Forty weeks after transplanting, each pot was supplied daily with a freshly prepared nutrient solution containing different concentrations of $\mathrm{Pb}\left(\mathrm{NO}_{3}\right)_{2}(0,100,200,400,600,800$ and $1000 \mathrm{mg} \mathrm{\textrm {L } ^ { - 1 } )}$ until the interstitial spaces between sand particles was completely filled. There were 15 pots per treatment in a completely randomized design. One month later, the leaves from all the treatments were observed.

\section{Observations}

Gas exchange parameters and chlorophyll a fluorescence measurements were determined after the treatment was stopped. Plants were sampled (at the 3-5th leaf from the top) to assess different physiological and biochemical index. After washing, the leaves were frozen in liquid $\mathrm{N}_{2}$ and stored at $80^{\circ} \mathrm{C}$ for biochemical analysis. The remaining plants were kept to assess their growth and yield-related traits.

\section{Leaf chlorophyll a fluorescence transient}

An OJIP transient was measured with a Handy Plant Efficiency Analyser (Handy PEA, Hansatech Instruments, Norfolk, U.K.) according to Strasser et al (1995) and Jiang et al (2008).

\section{Leaf gas exchange}

Leaf gas exchange measurements were performed by using a portable photosynthesis system (CID-301, USA) at an ambient $\mathrm{CO}_{2}$ concentration and with a photosynthetic photon flux (PPF) of $1000 \mu \mathrm{mol} \mathrm{m} \mathrm{m}^{-2} \mathrm{~s}^{-1}$ according to Qiu et al (2002). During the measurements, the leaf temperature and ambient vapor pressure were $26-30^{\circ} \mathrm{C}$ and $1.53 \pm 0.01 \mathrm{kPa}$, respectively.

\section{Determination of leaf pigment}

Leaf pigment was extracted and $\mathrm{Chl} a, \mathrm{Chl} b, \mathrm{Chl} \mathrm{a}+\mathrm{b}$ and $\mathrm{Car}$ were determined by following the methods of Arnon (1949) and Rao et al (1996). 


\section{Determination of Pb concentration and dry mass (DM)}

At the end of the experiment, 5 plants per treatment from five pots were harvested. The plants were divided into roots, stems and leaves. The plant materials were extensively washed with deionized water. They were then dried at $80{ }^{\circ} \mathrm{C}$ for $48 \mathrm{~h}$ and $\mathrm{DM}$ was measured according to Chen et al (2005). The $\mathrm{Pb}$ concentrations were determined according to Fang (1991).

\section{Soluble proteins and antioxidant enzyme activity}

Frozen leaf samples $(0.5 \mathrm{~g})$ were ground in liquid nitrogen with a mortar and pestle and homogenized in $5 \mathrm{ml}$ of $50 \mathrm{mM}$ sodium phosphate buffer ( $\mathrm{pH}$ 7.0). The homogenate was centrifuged at $11000 \mathrm{~g}$ for $20 \mathrm{~min}$ at $4^{\circ} \mathrm{C}$. The supernatant was collected and used for protein and antioxidant enzyme activity analyses. The soluble proteins were determined as described by Bradford (1976). The SOD activity was assayed by measuring its ability to inhibit the photochemical reduction of nitroblue tetrazolium as described by Stewart and Bewley (1980). POD activity was estimated by the method followed by Zhu (1990). CAT activity was estimated by using the Rao method (1996). APX activity was measured according to Nakano and Asada (1981).

\section{Determination of MDA}

Lipid peroxidation was determined by estimating the MDA content following the method described by Hodges et al (1999).

\section{Determination of $\mathrm{H}_{2} \mathrm{O}_{2}$}

The content of $\mathrm{H}_{2} \mathrm{O}_{2}$ was measured according to the method described by Orendi et al (2001).

\section{Determination of $\mathrm{O}_{2} \cdot{ }^{-}$generation}

The content of $\mathrm{O}_{2}{ }^{-}$- was assayed by its ability to reduce nitroblue tetrazolium (NBT) following the method described by Doke (1983).

\section{Determination of proline}

The proline content was determined according to the method used by Bates et al (1973).

\section{Statistical analysis}

The experiments were carried out with 3-15 replicates. An analysis of variance (ANOVA) was performed with a statistical package, namely Statistical Product and Service Solutions (SPSS) version 13.0, followed by the least significant difference (LSD) test at $\mathrm{p} \leq 0.05$. The results are presented as the means $\pm S D$.

\section{Conclusions}

When $D$. longan plants were subjected to $\mathrm{Pb}$ stress, they responded through alterations in their physiological and biochemical processes, which led to growth inhibition. $\mathrm{Pb}$ treatments induced increases in Fo, and they decreased the Fm, Fv, Fv/Fm, TRo/CSo, ETo/CSo, DIo/CSo, and RC/CSo. The decline in these parameters at high $\mathrm{Pb}$ stress was related to the loss of chlorophyll contents, leading to a significant decline in $\mathrm{Pn}, \mathrm{Tr}$, and Gs. Furthermore, $\mathrm{Pb}$ stress led to decreases in the soluble protein content, POD activity and increases in the SOD activity, proline and MDA contents, whereas CAT and APX were enhanced at low Pb levels and decreased under high $\mathrm{Pb}$ stress. These changes were closely related to the level of $\mathrm{Pb}$ stress and the interaction of these factors.

\section{Acknowledgments}

This research was supported by the National Natural Science Foundation Program (30400061), the National High Technology Research and Development Program ('863'Program 2007AA10Z227-2), the National Key Technology Support Program (2007BAD07B06-03), and the Natural Science Foundation of Fujian Province, China (2011J01082). The authors like to thank Dr. Xiangxi Xiao for his kind help with the experimental field and laboratory assays.

\section{References}

Apel K, Hirt H (2004) Reactive oxygen species: metabolism, oxidativestress, and signal transduction. Ann Rev Plant Biol. 55:373-379.

Arnon DI (1949) Copper enzymes in isolated chloroplasts. Polyphenoloxidase in Beta vulgaris. Plant Physiol. 24: 1-15.

Asada K (1996) The role of ascorbate peroxidase and monodehydroascorbate reductase in hydrogen peroxide scavenging in plants. In: Scandalios JG(ed) Oxidative Stress and the Molecular Biology of Antioxidant Defense, Cold Spring Harbor Laboratory Press, NewYork.

Bates LS, Waldren RP, Teare ID (1973) Rapid determination of free proline for water stress studies. Plant Soil. 39: 205-207.

Bharwana A, Ali S, Farooq MA, Iqbal N, Hameed A, Abbas F, Ahmad MSA (2014a) Glycinebetaine-induced lead toxicity tolerance related to elevated photosynthesis, antioxidant enzymes suppressed lead uptake and oxidative stress in cotton. Turkish J Bot. 38:281-292.

Bharwana SA, Ali S, Farooq MA, Ali B, Iqbal N, Abbas F, Ahmad MSA (2014b) Hydrogen sulfide ameliorates lead-induced morphological, photosynthetic, oxidative damages and biochemical changes in cotton. Environ Sci Pollut Res. 21:717-731.

Bradford MM (1976) A rapid and sensitive method for the quantification of microgram quantities of protein utilizing the principle of protein-dye binding. Analyt Biochem. 72; 248-254.

Bukhov NG, Sabat SC, Mohanty P (1990) Analysis of chlorophyll a fluorescence changes in weak light in heat treated Amarenthus chloroplasts. Photosyn Res. 23: 81-87.

Buonasera K, Lambreva M, Rea G, Touloupakis E, Giardi MT (2011) Technological applications of chorophyll a fluorescence for the assessment of environmental pollutants. Analyt Bioanalyt Chem. 401:1139-1151.

Cha-Um S, Kirdmane C (2009) Effect of salt stress on proline accumulation, photosynthetic ability and growth characters in two maize cultivars. Pakistan J Bot. 41: 87-98.

Chen LS, Qi YP, Smith BR, Liu XH (2005) Aluminum-induced decrease in $\mathrm{CO}_{2}$ assimilation in citrus seedlings is unaccompanied by decreased activities of key enzymes involved in $\mathrm{CO}_{2}$ assimilation. Tree Physiol. 25:317-324.

Cuchiara CC, Silva IMC, Martinazzo EG, Braga EJB, Bacarin MA, Peters PA (2013) Chlorophyll a fluorescence transient analysis in Alternanthera tenella Colla plants grown in nutrient solution with different concentrations of copper. J Agric Sci. 5: 8-16.

Doke N (1983) Involvement of superoxide anion generation in the hypersensitive response of potato tuber tissues to infection with an incompatible race of Phytophthora infestans and to the hyphal wall components. Physiol Mol Plant Pathol. 23: 345-357. 
Fang R (1991) Application of Atomic Absorption Spectroscopy in Sanitary Testing. Beijing University Press: Beijing, China

Gupta DK, Nicolosoa FT, Schetingerb MRC, Rossatoa LV, Pereirab LB, Castroa GY, Srivastavac S,Tripathi RD (2009) Antioxidant defense mechanism in hydroponi- cally grown Zea mays seedlings under moderate lead stress. J Hazard Mater. 172:479-484.

Han Y, Wang L, Zhang XL, Korpelainen H, Li CY (2013) Sexual differences in photosynthetic activity, ultrastructure and phytoremediation potential of Populus cathayana exposed to lead and drought. Tree Physiol. 33: 1043-1060.

Hodges DM, DeLong JM, Forney CF, Prange RK (1999) Improving the thiobarbituric acid-reactive-substances assay for estimating lipid peroxidation in plant tissues containing anthocyanin and other interfering compounds. Planta. 207:604-611.

Huang CJ, Wei G, Jie YC, Wang LC, Zhou HF, Ran CY, Huang ZC, Jia HJ, Anjum SA (2014) Effects of concentrations of sodium chloride on photosynthesis, antioxidative enzymes, growth and fiber yield of hybrid ramie. Plant Physiol Biochem. 76: 86-93.

Jiang HX, Chen LS, Zheng JG, Han S, Tang N, Smith BR (2008) Aluminum -induced effects on Photosystem II hotochemistry in Citrus leaves assessed by the chlorophyll a fluorescence transient. Tree Physiol. 28: 1863-1871.

Jiang Z, Zhang HN, Qin R, Zou JH, Wang JR, Shi QY, Jiang WS, Liu DH (2014) Effects of lead on the morphology and structure of the nucleolus in the root tip meristematic cells of Allium сера $\mathrm{L}$. Intern J Mol Sci. 15: 13406-13423.

Kanwal U, Ali S, Shakoor MB, Farid M, Hussain S, Yasmeen T, Adrees M, Bharwana SA, Abbas F (2014) EDTA ameliorates phytoextraction of lead and plant growth by reducing morphological and biochemical injuries in Brassica napus L. under lead stress. Environ Sci Pollut Res. 21:9899-9910.

Krause GH, Weis E (1991) Chlorophyll fluorescence and photosynthesis: the basics. Ann Rev Plant Physiol. 42: 313-349.

Lamhamdi M, Bakrim A, Aarab A, Lafont R, Sayah F (2011) Lead phytotoxicity on wheat (Triticum aestivum L.) seed germination and seedlings growth. Comptes Rendus Biologies. 334:118-126.

Mehta P, Jajoo A,Mathur S, Bharti S (2010) Chlorophyll a fluorescence study revealing effects of high salt stress on photosystem II in wheat leaves. Plant Physiol Biochem. 48:6-20.

Nakano Y, Asada K (1981) Hydrogen peroxide is scavenged by ascorbate-specic peroxidase in spinach chloroplasts. Plant Cell Physiol. 22:867-880.

Orendi G, Zimmermann P, Baar C, Zentgraf U (2001) Loss of stress-induced expression of catalase during leaf senescence in Arabidopsis thaliana is restricted to oxidative stress. Plant Sci. 161: 301-314.

Pinho S, Ladeiro B (2012) Phytotoxicity by lead as heavy metal focus on oxidative stress. J Bot. 1-11.

Pourrut B, Shahid M, Dumat C, Winterton P, Pinelli E (2011) Lead uptake, toxicity, and detoxification in plants. Rev Environ Contam Toxicol. 213:113-136.

Qiu DL (2014) Longan production and research in China. Acta Hort. 1029: 139-146.

Qiu DL, Liu XH,Guo SZ (2002) Effects of simulated acid rain stress on gas exchange and chlorophyll a fluorescence parameters in leaves of longan. Acta Phytoecol Sin. 26: 441-446.

Rao MV, Paliyath G, Ormrod DP (1996) Ultraviolet-B-and ozone-induce biochemical changes in antioxidant enzymes of Arabidopsis thaliana. Plant Physiol. 110; 125-126.

Reddy A, Kumar S, Jyonthsnakumari G, Thimmanaik S, Sudhakar S (2005) Lead induced changes in antioxidant metabolism of horsegram (Macrotyloma uniflorum (Lam.) Verdc.) and bengalgram (Cicer arietinum L.). Chemosphere. 60: 97-104.
Rohácek K (2002) Chlorophyll fluorescence parameters: the definitions, photosynthetic meaning, and mutual relationships. Photosynthetica. 40:13-29.

Sengar RS, Gautam M, Sengar RS, Garg SK, Sengar K, Chaudhary R (2008) Lead stress effects on physiobiochemical activities of higher plants. In: Whitacre DM(ed) Reviews of Environmental Contamination and Toxicology, Springer, Berlin, p 73-93.

Shakoor MB, Ali S, Hameed A, Farid M, Hussain S, Yasmeen, T, Najeeb U, Bharwana SA, Abbasi GH (2014) Citric acid improves lead (pb) phytoextraction in Brassica napus L. by mitigating pb-induced morphological and biochemical damages. Ecotoxicol Environ Safety. 109:38-47.

Shamsi IH, Jilani G, Zhang GP, Kang J (2008) Cadmium stress tolerance through potassium nutrition in soybean. Asian $\mathrm{J}$ Chem. 20: 1099-1108.

Sharma P, Dubey RS (2005) Lead toxicity in plants. Brazilian J Plant Physiol. 17: 35-52.

Shu X, Yin LY, Zhang QF, Wang WB (2012) Effect of Pb toxicity on leaf growth, antioxidant enzyme activities, and photosynthesis in cuttings and seedlings of Jatropha curcas L. Environ Sci Pollut Res. 19:893-902.

Stewart RC, Bewley JD (1980) Lipid peroxidation associated with accelerated ageing of soybean. Plant Physiol. 65: 245-248.

Strasser RJ, Srivastava A, Govindjee (1995) Polyphasic chlorophyll a fluorescence transient in plants and cyanobacteria. Photochem Photobiol. 61: 32-42.

Strasser RJ, Stirbet AD (1998) Heterogeneity of Photosystem II probed by the numerically simulated chlorophyll a fluorescence rise (O-J-I-P). Math Comput Simul. 48:3-9.

Strasser RJ, Tsimilli-Michael M, Srivastava A (2004) Analysis of the fluorescence transient. In:Papageorgiou and Govindjee GC(eds) Chlorophyll Fluorescence: A Signature of Photosynthesis, Springer, Berlin, p 321-362.

Tsimilli-Michael M, Strasser RJ (2008) In vivo assessment of plants vitality: applications in detecting and evaluating the impact of Mycorrhization on host plants. In: Varma A(ed) Mycorrhiza: State of the Art, Genetics and Molecular Biology, Eco-Function, Biotechnology, Eco-Physiology, Structure and Systematics, Springer. Berlin, p 679-703.

Verma S, Dubey RS (2003) Lead toxicity induces lipid peroxidation and alters the activities of antioxidant enzymes in growing rice plants. Plant Sci. 164: 645-655.

Wang CR, Gu XY, Wang XR, Guo HY, Geng JJ, Yu HX, Sun J (2011) Stress response and potential biomarkers in spinach (Spinacia oleracea L.) seedlings exposed to soil lead. Ecotoxicol Environ Safety. 74: 46-47.

Wang RJ,Zhuang YM (1981) Primary study on nutrient deficiency in longan. Subtrop Plant Sci. 2:5-10.

Yamane Y, Kashino Y, Koike H, Satoh K (1997) Increases in the fluorescence Fo level and reversible inhibition of Photosystem II reaction center by high-temperature treatments in higher plants. Photosyn Res. 52:57-64.

Yang G, Yang L, Jiang YL, Li Y, Wang P, Chen L (2012) Physiological impacts of magnesium-deficiency in citrus seedlings: photosynthesis, antioxidant system and carbohydrates. Tree Struct Funct. 26:1237-1250.

Yusuf MA, Kumar D, Rajwanshi, R, Strasser RJ, Tsimilli-Michael M, Govindjee, Sarin NB (2010) Overexpression of $\gamma$-tocopherol methyltransferase gene in transgenic Brassica juncea plants alleviates abiotic stress: Physiological and chlorophyll a fluorescence measurements. Biochi Biophys Acta. 1797: 1428 -1438.

Zhang H, Ye YK, Wang SH, Luo JP, Tang J, Ma DF (2009) Hydrogen sulphide counteracts chlorophyll loss in sweet potato seedling leaves and alleviates oxidative damage against osmotic stress. Plant Growth Regul. 58: 243-250.

Zhu GL (1990) Plant Physiology Experiment. Beijing University Press: Beijing, China. 